\title{
A cryopreservative procedure for storing cultivated and uncultivated amniotic fluid cells in liquid nitrogen
}

\author{
S PENTZ AND H HÖRLER \\ From the Abteilung Klinische Genetik, University of Ulm, D-7900 Ulm, Federal Republic of Germany
}

SUMMARY The cryopreservation of cultured and uncultured amniotic fluid cells is of special importance in prenatal diagnosis. The freezing procedure presented gave a cell recovery of about $95 \%$ for cultivated human amniotic fluid cells combined with a rapid appearance of mitosis after inoculation.

A number of inborn errors of metabolism can be detected prenatally in amniotic fluid cells. Diagnosis of these metabolic defects requires cultivated control cells from the amniotic fluid. For this reason, it is important to be able to store cells for long periods of time for prenatal diagnosis. However, variation in metabolic processes often takes place during the cultivation, depending on the cell culture conditions, the number of passages, and the momentary phase of growth. Heukels-Dully and Niermeijer ${ }^{1}$ estimated a time-related variation in lysosomal enzyme specific activity in subcultivated amniotic fluid cells, but it should also be noted that activity of some lysosomal enzymes are relatively stable in primary cultures. It is for this reason that adequate control cultures for biochemical analysis should be available at all times, hence the need for uncultured amniotic fluid cells stored in liquid nitrogen. ${ }^{2}$

Together with glycerol, dimethyl sulphoxide (DMSO) is the most useful cryopreservative agent. The latter has a high penetration rate through cell membranes and can be easily washed out after the thawing process. ${ }^{34}$ In addition, DMSO possesses good colligative properties. ${ }^{5}$ Many investigators have shown that DMSO is especially toxic when the temperature is increased $\left(0\right.$ to $\left.37^{\circ} \mathrm{C}\right) .^{6-8}$ Hak et al ${ }^{9}$ and Alink et al ${ }^{10}$ showed that the toxic effects of DMSO on beating heart cells in vitro could be reduced when DMSO was added slowly to cells before the freezing process and its concentration slowly reduced on thawing. It is assumed that by this procedure the damaging effect of DMSO on the cell membrane by osmotic stress can be avoided.

The following report is a description of a cell

Received for publication 30 January 1980 freezing process which does not subject the cells to harsh treatment, has a high cell recovery, and a rapid cell regeneration after thawing.

\section{Materials and methods}

FREEZING PROCEDURE

Uncultivated amniotic fluid cells $(5 \mathrm{ml}$ amnioti fluid/sample) were centrifuged for 10 minutes $135 \mathrm{~g}$ and the amniotic fluid discarded. Cultivateđ amniotic cells were washed with Hank's balanced salt solution (BSS) and treated with $0.25 \%$ trypsin and $0.2 \%$ EDTA $(6: 4)$ to release adherent cells. Serum was added to the resulting cell suspension in a ratio of 2:1 and centrifuged in polycarbonate tubes (Greiner, D-7440 Nürtingen), resuspended, and centrifuged again. The supernatant was discarded and the cells resuspended in Eagle's MEM medium containing Earle's salts, 20\% FCS (Seromed, D-8000 München), $5 \%$ L-glutamine, 100 IU penicillin $/ \mathrm{ml}$, and $100 \mu \mathrm{g}$ streptomycin $/ \mathrm{ml}$. The tubes were then placed in iced water. For a final DMSO concentration of $5 \%$, a $9.2 \%$ DMSO solution in MEM was prepared and $0.6 \mathrm{ml}$ of this precooled solution was added drop by drop to $0.5 \mathrm{ml}$ ? of the cell suspension. Addition of this solution to the cell suspension was carried out within 6 minutes. N It was performed in our laboratory using an automatic time-pipette.

One $\mathrm{ml}$ of the DMSO-cell suspension was added $\mathrm{N}$ aseptically to precooled freezing vials (Polypropylene, Greiner) and closed tightly. The optimal cell con- 0 centration of amniotic fluid cells was found to be $\mathbb{D}$ between $5 \times 10^{5}$ and $2 \times 10^{6} \mathrm{cells} / \mathrm{ml}$. For freezing, a liquid nitrogen container type LR-33-10 (Union 
Carbide) was used from which the normal lid was removed. In its place was inserted a special adaptor lid together with a freezing vial holder (BF-6). The freezing vial holder was set in the $E$ position and filled with 5 vials. The rate of freezing was measured as approximately $1.6^{\circ} \mathrm{C} / \mathrm{min}$ in the liquid phase and $1.4^{\circ} \mathrm{C} / \mathrm{min}$ in the solid phase, as recommended by the manufacturers. Freezing to $-70^{\circ} \mathrm{C}$ then takes about 100 minutes. This time is constant when the freezing container is 70 to $80 \%$ full of liquid nitrogen.

\section{THAWING OF CELLS}

The freezing vials were taken out of the liquid nitrogen container and put directly into a $37^{\circ} \mathrm{C}$ water bath. The vials were shaken in the water bath until only a small ball of ice remained. The cell suspension was then pipetted into a centrifuge tube which had previously been cooled, and $9 \mathrm{ml}$ of cooled culture medium was added in drops within 9 minutes. Since the cells adhere to glass, plastic tubes were used. The cells were washed twice with medium and centrifuged between each wash. The cells were then resuspended in a culture flask with medium supplemented with $20 \%$ FCS.

\section{EXPERIMENTAL METHOD}

Cells from a culture flask were divided into three equal parts and the recovery determined according to the following scheme.

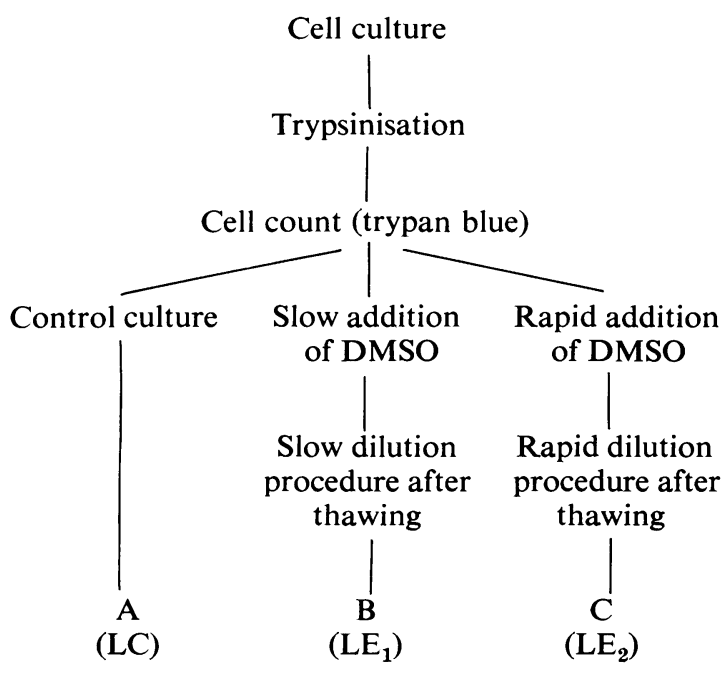

Twenty-four hours after cell cultivation, the floating cells were counted and dead cells were evaluated using the trypan blue method (LC = dead cells in the control culture; $\mathbf{L E}=$ dead cells after cryopreservative procedure).

Calculation of the recovery $=$

$$
\frac{100-(\mathrm{LE} / \mathrm{ml}-\mathrm{LC} / \mathrm{ml}) \times 100}{\text { total plated cell count } / \mathrm{ml}}
$$

\section{Results}

The results from cell cultures show that recovery is significantly higher $(\mathrm{p}<0.01)$ when DMSO is added slowly before freezing and slowly diluted after thawing than when DMSO is added rapidly. The latter process also gives rise to a greater variation in results (table 1). Furthermore, as with normal cultures, cell division of cultured amniotic cells subjected to cryopreservation by the slower procedure

TABLE 1 Recovery of cultivated amniotic fluid cells after slow $(B)$ and rapid $(C)$ DMSO addition

\begin{tabular}{lrrll}
\hline Culture No & Total cell count & \multicolumn{2}{l}{ Recovery } \\
\cline { 4 - 5 } & & & $B(\%)$ & $C(\%)$ \\
\hline A & 884 & 1045000 & $94 \cdot 74$ & $83 \cdot 68$ \\
A & 969 & 1975000 & $91 \cdot 04$ & $78 \cdot 20$ \\
A & 1230 & 850000 & $91 \cdot 18$ & $82 \cdot 65$ \\
A & 1038 & 1270000 & $97 \cdot 24$ & $82 \cdot 48$ \\
Ac & 118 & 755000 & $97 \cdot 15$ & $84 \cdot 83$ \\
A & 348 & 1380000 & $90 \cdot 29$ & $62 \cdot 39$ \\
A & 326 & 2270000 & $100 \cdot 57$ & $90 \cdot 42$ \\
A & 856 & 1530000 & $96 \cdot 86$ & $77 \cdot 35$ \\
Ac & 98 & 960000 & $94 \cdot 79$ & $82 \cdot 92$ \\
A & 1213 & 880000 & $89 \cdot 77$ & $63 \cdot 24$ \\
A & 1615 & 625000 & $95 \cdot 09$ & $84 \cdot 97$ \\
A & 1469 & 1300000 & $91 \cdot 15$ & $89 \cdot 73$ \\
A & 828 & 920000 & $91 \cdot 85$ & $75 \cdot 33$ \\
A & 924 & 1485000 & $94 \cdot 48$ & $84 \cdot 88$ \\
A & 873 & 1150000 & $98 \cdot 00$ & $85 \cdot 65$ \\
A & 1484 & 970000 & 99.43 & $84 \cdot 07$ \\
& & & $\bar{x}=94.60 \pm 3 \cdot 42$ & $80 \cdot 36 \pm 7 \cdot 71$ \\
\hline
\end{tabular}

TABLE 2 Number of colonies from uncultured amniotic cells inoculated before and after the freezing procedure

\begin{tabular}{llcc}
\hline Culture No & Gestation week & $\begin{array}{l}\text { Colonies from cells of } 5 \mathrm{ml} \\
\text { amniotic fluid }\end{array}$ \\
\cline { 3 - 4 } & & Direct culture & $\begin{array}{c}\text { Culture after } \\
\text { freezing }\end{array}$ \\
\hline Ac 50 & 15 & 8 & 7 \\
Ac 51 & 14 & 5 & 12 \\
Ac 52 & 14 & 14 & 11 \\
Ac 53 & 14 & 7 & 9 \\
Ac 54 & 18 & 9 & 4 \\
Ac 56 & 17 & 2 & 5 \\
Ac 57 & 18 & 17 & 18 \\
Ac 58 & 14 & 10 & 8 \\
Ac 59 & 14 & 7 & 7 \\
Ac 61 & 14 & 8 & 19 \\
Ac 62 & 17 & 22 & 11 \\
Ac 63 & 16 & 12 & 19 \\
\hline
\end{tabular}


occurs between 2 and 6 hours after inoculation (B, $L_{1}$ ), while division of the cells using the rapid procedure occurs between 10 and 12 hours. Table 2 shows that there is no difference between the number of colonies from uncultured amniotic cells inoculated before and after the freezing procedure.

\section{Discussion}

The results indicate that the modified cryopreservation procedure described here ensures a rapid supply of uncultivated and cultivated amniotic cells. In addition, no difference was observed between the number of colonies of uncultured amniotic fluid cells before or after storage in liquid nitrogen. With respect to the appearance of the first dividing cells, we did not find any difference between direct culture and cultivation after freezing and thawing. ${ }^{2}$ A recovery of approximately $95 \%$ and an earlier appearance of mitotic cells were found in cultures of cultivated amniotic cells after the special slow freezing and thawing method. Using the rapid procedure a lower recovery was obtained $(80 \%)$ and mitosis of the cells occurred at a later stage than by the slower method. Both procedures may be compared favourably with those of some other investigators which may possibly be the result of the careful handling of cells before cryopreservation, for example, through the rapid inactivation of the enzymatic activity of trypsin after detachment of the cells from the cultivation surface. Ashwood et al ${ }^{11}$ obtained a similariy high recovery of $91 \%$ in cultures of Chinese hamster ovary fibroblasts after slow addition of DMSO to the cell suspension 10 to 15 minutes before the freezing procedure was started. The low concentration of DMSO $(5 \%)$, together with the low but increasing temperature $\left(4^{\circ} \mathrm{C}\right.$ to $16^{\circ} \mathrm{C}$ ), obviously reduces the toxicity of the cryopreservative agent. Niermeijer $e t a l^{2}$ showed that a DMSO concentration of $4 \%$ was just within the protection range for uncultivated amniotic fluid cells. An even lower DMSO concentration has, according to Alink et al, ${ }^{10}$ extremely reduced cryopreservative properties, as well as increasing the probability of micro-damage to the cells. ${ }^{12}$ Many authors have described microscopic damage to cell membranes and organelles of living cells after suboptimal freezing procedures. ${ }^{13-15}$ Alink et $a l^{16}$ showed, using electron microscopy, that only after an 8-day period is regeneration of microscopic damage complete.

With regard to cell recovery, a comparison in procedure with other laboratories is difficult since many methods have been used in the past. Recovery is, however, frequently measured as the "plating efficiency' which has been defined by Fedoroff ${ }^{17}$ as the "percentage of inoculated cells which gave rise to $\mathbb{D}$ colonies". So that an optimal number of colonies $\mathbb{\Phi}$ can be counted, a correspondingly low cell dilution must be inoculated. However, plating a low cell $\stackrel{0}{\rightarrow}$ concentration of mammalian cells usually results in흐 little or no culture growth. For this reason, other흠 methods have been described to measure the $\frac{\bar{\rho}}{\partial}$ recovery of diploid mammalian cells. ${ }^{1518} 19$ The $\stackrel{\mathbb{\Phi}}{\Omega}$ method employed here to determine the cell recovery for cultivated amniotic cells is a combination of the 'floating cell method' described by Priest et $a l^{18}$ and. the method described by Hunt et al, ${ }^{15}$ in which a $\overrightarrow{\vec{\omega}}$ comparison is made with unfrozen control cultures, $\stackrel{\omega}{\stackrel{\omega}{\circ}}$ both methods relying on a measurement after a 24 hour cell incubation period. A trypan blue determination of dead cells between 2 and 8 days of $\vec{v}$ incubation would indicate lethal damage, for example, after a suboptimal cryopreservation $\stackrel{A}{N}$ process. ${ }^{10}$ However, the results could be questioned $\mathrm{N}$ on the grounds of uncontrollable external toxic factors. ${ }^{19}$ Counting floating cells after incubation ${ }^{18}{ }^{19} \vec{\square}$ is therefore considered by some authors to be a better $\mathbb{D}$ choice for determining cell recovery than counting $\frac{\mathbb{}}{3}$ and staining after cell trypsinisation, since an $\frac{}{0}$ adequate control is not possible in the latter case..$^{15} \stackrel{\Phi}{=}$ A comparison with an unfrozen control culture is $\overrightarrow{0}$ similarly necessary since cellular damage can occug ${ }^{\circ}$ for example, through trypsinisation ${ }^{16}$ followed cultivation, and cannot be separated from tox substances or processes which occur in the cryळpreservation system.

It is for this reason that further experiments in this $\frac{\nexists}{8}$ field will be concerned with cell lines from cloned, $\stackrel{\square}{\longrightarrow}$ morphologically different cells obtained from $\overrightarrow{\overrightarrow{0}}$ amniotic cell cultures and the recovery of these cells 3 measured after cryopreservation using different conditions.

This investigation was supported by the Deutschen Forschungsgemeinschaft (Pe 191/2-6, prenatal diagnosis).

\section{References}

1 Heukels-Dully MJ, Niermeijer MF. Variation in lysosomal enzyme activity during growth in culture of human fibroblasts and amniotic fluid cells. Exp Cell Res 1976; 97:304-12.

2 Niermeijer MF, Halley D, Sachs E, Tichelaar-Klepper C. Transport and storage of amniotic fluid samples for prenatal diagnosis of metabolic diseases. Humangenetik $\mathrm{W}$ $1973 ; 20: 175-8$.

3 Bickis IJ, Kasaks K, Finn JJ, Henderson WD. Permeation kinetics of glycerol and dimethyl sulfoxide in Novikoff hepatoma ascites cells. Cryobiology 1967;4:1-10.

4 Meryman HT. Cryoprotective agents. Cryobiology $1971 ; 8: 173-83$.

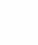


5 Ashwood-Smith MJ. Radioprotective and cryoprotective properties of DMSO. In: Jacob SW, Rosenbaum EE, Wood DC, eds. Dimethyl sulphoxide. New York: Dekker, 1971:147-88.

6 Malinin TI, Perry VP. Toxicity of dimethyl sulfoxide on HeLa cells. Cryobiology 1967;4:90-6.

7 Karow AM, Carrier O, Holland WC. Toxicity of high dimethylsulfoxide concentrations in rat heart freezing. Cryobiology 1967;3:464-8.

8 Mason MM. Toxicology of DMSO in animals. In: Jacob SW, Rosenbaum EE, Wood DC, eds. Dimethyl sulfoxide. New York: Dekker, 1971:113-31.

9 Hak AM, Offerijns FGJ, Verheul CC. Toxic effects of DMSO on cultured beating heart cells at temperature above zero. Cryobiology 1973;10:244-50.

10 Alink GM, Verheul CC, Offerijns FGJ. The effect of cooling rate and of dimethyl sulfoxid concentration on low temperature preservation of neonatal rat heart cells. Cryobiology 1976;13:295-304.

11 Ashwood MJ, Friedmann GB. Lethal and chromosomal effects of freezing, thawing, storage time and $\mathrm{X}$-irradiation on mammalian cells preserved at $-196^{\circ} \mathrm{C}$ in dimethyl sulfoxide. Cryobiology 1979;16:132-40.

12 Trump BF, Young DE, Arnold EA, Stowell RE. Effect of freezing and thawing on the structure, chemical constitution and function of cytoplasmic structures. Fed Proc 1965;24:114-68.
13 Bank H, Mazur P. Relation between ultrastructure and viability of frozen-thawed Chinese hamster tissue culture cells. Exp Cell Res 1972;71:441-54.

14 Beadle DJ, Harris LW. Relationship between freezing rate, ultrastructure and recovery in a human diploid cell line. J Cell Sci 1974;15:419-27.

15 Hunt CJ, Beadle DJ, Harris LW. An ultrastructure study of the recovery of Chinese hamster ovary cells after freezing and thawing. Cryobiology 1977;14:135-43.

16 Alink GM, Agterberg J, Helder AW, Offerijns FGJ. The effect of cooling rate and of dimethyl sulfoxid concentration on the ultrastructure of neonatal rat heart cells after freezing and thawing. Cryobiology 1976; 13:305-16.

17 Fedoroff S. Proposed usage of animal tissue culture terms. $J$ Natl Cancer Inst 1967;38:607-11.

18 Priest JH, Baxter LK, Priest RE. Cell attachment assay as a measure of thawed cell viability. Cryobiology 1965;1: 345-7.

19 von Böhmer H, Wöhler W, Wendel U, Passarge E, Rüdiger HW. Studies on the optimal cooling rate for freezing human diploid fibroblasts. Exp Cell Res 1973;79:496-8.

Requests for reprints to Dr S Pentz, Abteilung Klinische Genetik, Universität Ulm OE, D-7900 Ulm, Federal Republic of Germany. 